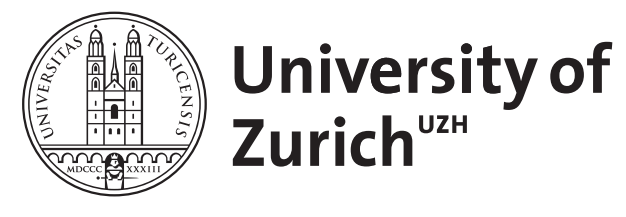

\title{
A visual stimulus for eliciting associated motion
}

Vuillermet, Marine

\begin{abstract}
Pictures and video stimuli help investigate specific semantic domains and/or grammatical categories. Such stimuli not only help to collect more occurrences of a given (possibly rare) morpheme in a semi-spontaneous setting, but also allow the study of variation across speakers and diversity across languages. The paper describes a stimulus in the form of a storybook, A Hunting Story, specifically conceived to elicit associated motion (AM) morphemes in Ese Ejja, an Amazonian language with a complex system of 14 such morphemes. The pictures of the storybook therefore represent an Amazonian setting, and the scenario incorporates the main parameters established in the AM literature (such as path/directionality, temporal relation, moving argument), as well as less frequent ones (such as aspectual realization). The paper describes the data collected from 14 speakers of Ese Ejja as well as data collected with the same stimulus in other languages, including languages with no morphological AM system.
\end{abstract}

DOI: https://doi.org/10.1515/9783110692099-006

Posted at the Zurich Open Repository and Archive, University of Zurich

ZORA URL: https://doi.org/10.5167/uzh-201300

Book Section

Published Version

Originally published at:

Vuillermet, Marine (2021). A visual stimulus for eliciting associated motion. In: Guillaume, Antoine; Koch, Harold. Associated Motion. Amsterdam: Walter de Gruyter, 201-228.

DOI: https://doi.org/10.1515/9783110692099-006 
Associated Motion 


\section{Empirical Approaches to Language Typology}

Editors

Georg Bossong

Bernard Comrie

Kristine Hildebrandt

Jean-Christophe Verstraete

Volume 64 


\section{Associated Motion}

Edited by

Antoine Guillaume

Harold Koch

\section{DE GRUYTER}

MOUTON 
ISBN 978-3-11-069200-6

e-ISBN (PDF) 978-3-11-069209-9

e-ISBN (EPUB) 978-3-11-069212-9

Library of Congress Control Number: 2021930508

Bibliographic information published by the Deutsche Nationalbibliothek

The Deutsche Nationalbibliothek lists this publication in the Deutsche Nationalbibliografie; detailed bibliographic data are available on the Internet at http://dnb.dnb.de.

(C) 2021 Walter de Gruyter GmbH, Berlin/Boston Typesetting: Integra Software Services Pvt. Ltd.

Printing and binding: $\mathrm{CPI}$ books, $\mathrm{GmbH}$, Leck

www.degruyter.com 


\section{Contents}

\section{Part I: Perspectives and general issues}

Antoine Guillaume and Harold Koch

1 Introduction: associated motion as a grammatical category in linguistic typology -3

Daniel Ross

2 A cross-linguistic survey of Associated Motion and Directionals - 31

Joseph Lovestrand and Daniel Ross

3 Serial verb constructions and motion semantics 87

Matthew S. Dryer

4 Associated motion and directionals: where they overlap - 129

Aïcha Belkadi

5 Deictic directionality as associated motion: motion, complex events and event integration in African languages - 163

Marine Vuillermet

6 A visual stimulus for eliciting associated motion -201

\section{Part II: Australia and South Pacific}

Harold Koch

7 Associated motion in the Pama-Nyungan languages of Australia -231

David Osgarby

8 Mudburra associated motion in an areal perspective -325

Lauren W. Reed and Kate L. Lindsey

9 "Now the story's turning around": Associated motion and directionality in Ende, a language of Papua New Guinea — 357 
Dineke Schokkin

10 Preverbal directionals as markers of associated motion in Paluai (Austronesian; Oceanic) -385

\section{Part III: The Americas}

Adam J.R. Tallman

11 Associated motion in Chácobo (Pano) in typological perspective - 419

Alejandra Vidal and Doris L. Payne

12 Pilagá directionals and the typology of associated motion -451

Matthew S. Dryer

13 Associated motion in North America (including Mexico and Central America) -485

Néstor Hernández-Green and Enrique L. Palancar

14 Associated motion in the Otomi family -527

\section{Part IV: Africa}

Rozenn Guérois, Hannah Gibson and Bastian Persohn

15 Associated motion in Bantu languages - 569

\section{Sylvie Voisin}

16 Associated motion and deictic directional in Atlantic languages - 611

Denis Creissels and Alain Christian Bassène

17 Ventive, associated motion and aspect in Jóola Fóoñi (Atlantic) - 665

Doris L. Payne

18 The extension of associated motion to direction, aspect and argument structure in Nilotic languages - 695

Kazuhiro Kawachi

19 The 'along'-deictic-directional verb suffix complex in Kupsapiny — 747 
Manuel A. Otero

20 At the intersection of associated motion, direction and exchoative aspect in the Koman languages -779

\section{Part V: Asia}

Guillaume Jacques, Aimée Lahaussois and Shuya Zhang

21 Associated motion in Sino-Tibetan, with a focus on Gyalrongic and Kiranti -819

Brigitte Pakendorf and Natalia Stoynova

22 Associated motion in Tungusic languages: a case of mixed argument structure -855

Subject Index - 899

Language Index -907

Name Index — 917 



\title{
6 A visual stimulus for eliciting associated motion
}

\begin{abstract}
Pictures and video stimuli help investigate specific semantic domains and/or grammatical categories. Such stimuli not only help to collect more occurrences of a given (possibly rare) morpheme in a semi-spontaneous setting, but also allow the study of variation across speakers and diversity across languages. The paper describes a stimulus in the form of a storybook, A Hunting Story, specifically conceived to elicit associated motion (AM) morphemes in Ese Ejja, an Amazonian language with a complex system of 14 such morphemes. The pictures of the storybook therefore represent an Amazonian setting, and the scenario incorporates the main parameters established in the AM literature (such as path/directionality, temporal relation, moving argument), as well as less frequent ones (such as aspectual realization). The paper describes the data collected from 14 speakers of Ese Ejja as well as data collected with the same stimulus in other languages, including languages with no morphological AM system.
\end{abstract}

Keywords: experimental stimulus, visual stimulus, elicitation, associated motion, Amazonian languages

\section{Introduction: a visual stimulus for eliciting associated motion}

Pictures and video stimuli have long proven to be useful in investigating specific semantic domains and/or grammatical categories (e.g. Hellwig 2006), especially for comparative work (e.g. Levinson et al. 2003; or Kopecka \& Narasimhan 2012). A Hunting Story (Vuillermet \& Desnoyers 2013) is the first storybook conceived to elicit Associated Motion (henceforth AM), i.e. morphemes or constructions which mark the association of a backgrounded motion to a main action (Koch 1984; Wilkins 1991; Guillaume 2006 , 2016; Guillaume \& Koch this volume). This storybook was specifically designed to collect AM morphemes in Ese Ejja, an Amazonian language from the Pano-Takanan family of Bolivia and Peru that displays a

\footnotetext{
Marine Vuillermet, Department of Comparative Language Science \& Center for the Interdisciplinary Study of Language Evolution, University of Zürich \& Laboratoire Dynamique du Langage (CNRS \& Université Lumière Lyon 2), marine.vuillermet@uzh.ch
} 
very complex system of 14 AM verbal affixes. For instance, example (1), collected with the Hunting Story stimulus, illustrates the Ese Ejja AM morpheme -ña Do.ARRIVING which indicates that the (non-motion) event of eating will happen upon the arrival of the speaker. ${ }^{1}$

(1) 'Bo'bi-kwakwa, iya-'io-kwe ekweya e-ijjia-ña-’io-jji,

food-cooked sit.TR-TEL-IMP 1GEN PURP-eat-Do_ARRIVING-TEL-PURP

kia-shoe-nei-nei=ya kwe-je-'io eya.

APF-hungry-very-very=FOC come-FUT-TEL 1SG.ABS

'Put cooked food aside for me to eat (when I arrive), I will arrive home very hungry.' \{JulHS01\}

All the pictures in this storybook illustrate main actions that occur in the context of a journey - e.g. eating while arriving, as in (1), checking the rifle before leaving, waving to one's family while going away, greeting friends passing by, etc. This particular stimulus aims to:

1. facilitate the collection of AM morphemes and yield a greater number of tokens, produced in a variety of contexts;

2. better understand the semantic features of each AM morpheme and of the system as a whole (inventory);

3. allow the comparison of intraspeaker and interspeaker variation and examine the possible influence of various parameters such as age, gender and level of fluency;

4. permit the investigation of the discourse use of the morphemes;

5. enable cross-linguistic comparisons, in terms of inventories and discourse use;

6. study AM with an onomasiological approach, i.e. as a functional domain, by examining any strategy used to co-express a non-motion and a (backgrounded) motion event (instead of AM morphology alone).

The storybook is accompanied by a protocol for its use. ${ }^{2}$ They are the result of a one-year postdoctoral fellowship at the University of California, Berkeley; the

1 All examples in this paper are responses to the stimulus 'A Hunting Story'. In the translation line, HS\#\# in brackets indicates the page number of the picture described, preceded by the recording ID used by the researcher.

2 Both are available online at the TulQuest archive for linguistic questionnaires (http://tulquest. huma-num.fr/fr/node/46). TulQuest is an online interactive archive developed by a research team led by A. Lahaussois (HTL, CNRS) and supported by the CNRS Fédération de Typologie et Universaux Linguistiques (TUL, FR2559) between 2014 and 2018. The archive allows users to both retrieve and deposit Questionnaires, defined by our project as any methodological tool de- 
Fyssen Foundation provided the financial support, and Antoine Desnoyers, a painter and graphic-designer, effected the drawings. ${ }^{3}$

The present paper is organized as follows: Section 2 details the parameters selected to design the stimulus, and discusses the various domains one might want to explore. Section 3 presents the entire kit: the AM storybook and its 22 scenes, the precautions to be taken to ensure that the pictures are accessible to people unfamiliar with Western modes of representation, and the optional steps in the protocol. Section 4 examines the AM morphemes collected in the Ese Ejja Hunting Stories. Section 5 offers a glance at data collected by other researchers using the stimulus in languages with or without AM morphology, not only spoken in Amazonia but also Nepal and Papua New Guinea.

\section{The etic grid and the domains to be explored}

\subsection{Parameters identified and selected for the AM storybook A Hunting Story}

According to the descriptions of complex ${ }^{4}$ AM systems currently available, three main parameters play a role:

- $\quad$ PATH / DIRECTIONALITY - motion away or towards a point of reference, distributed over space, and, much less frequently, upward /downward, as e.g. in Arrernte (Pama-Nyungan) in Wilkins (1991), or reversive, as in Mojeño Trinitario (Arawak; Rose 2015: 144);

- TEMPORAL RELATION TO THE MAIN ACTION - motion event is prior, concurrent or subsequent, as e.g. in Kaytetye (Pama-Nyungan) in Koch (1984: 26) or in Cavineña (Pano-Takanan) in Guillaume (2009);

- MOVING ARGUMENT - the subject, the object (e.g. Guillaume 2016) or, exceptionally, a non-core argument, as in Arrernte (Wilkins 1991: 236-238).

signed to collect linguistic data. The archived Questionnaires are categorized according to a taxonomy of features and written with a capital letter to highlight this special use of the term, and are accompanied by additional materials beyond basic metadata, ranging from a summary of usage protocol, development context, reviews and user tips, as well as the possibility of linking together questionnaires that have been adapted from an original version, reflecting the dynamic nature of questionnaire use. See Lahaussois (2019) for more details.

3 www.antoinedesnoyers.com

4 "Complex" here is used in the sense of Guillaume (2016: 109), who distinguishes between three levels of complexity in the system of Amazonian languages: simple systems (1 or 2 AM morphemes), complex systems ( 3 to 5 AM morphemes) and very complex ones (6 or more AM morphemes). 
Other attested parameters are:

- ASPECTUAL REALIZATION (ongoing vs. punctual main action, e.g. 'do all along or repeatedly' vs. 'do only once during a translational motion');

- FEATURES OF THE GROUND (new or topic, as distinguished in Yagua (isolate; Payne 1984), permanent, unstable or transitional); ${ }^{5}$

- the TYPE OF RELATION between the action and the motion (purpose vs. plain temporal relation, e.g. in Ese Ejja (Vuillermet 2013: 47), -ki 'go to do' vs. -ña 'do arriving');

- the MANNER (hurried or unspecified, as in Arrernte (Wilkins 1991: 235)).

This list of parameters constitutes the etic grid (Majid 2012: 62-65) for this stimulus. The storybook takes into account all these parameters (but the manner) and contrasts most values. (See Table 1 in $\S 3$ for the list of the concepts targeted with each scene.)

\subsection{Goals and domains explored}

The main goals of the stimulus are to collect more AM morphemes, and to investigate which semantic features a given system is sensitive to. Is "subsequent motion" part of the system or is the AM system restricted to prior (and concurrent) motion (cf. Guillaume's (2016: 90) implicational scale)? Is the reference point the speaker, or any salient place or entity from the previous discourse? Additional goals are as follows:

\section{Discourse use}

The stimulus helps examine the AM system of a language in terms of discourse use. How systematic is the use of AM morphemes? In a language with AM morphemes encoding different temporal relations to the main action, are the prior, concurrent and subsequent motion used (a) symmetrically; i.e. are prior motion AM forms for instance more frequent? Does the language manifest the "echo phenomenon” (Wilkins 1991: 251; Guillaume 2006: 424, 432) and if it does, how systematic is it? Which main path verbs (e.g. 'go', 'come', 'move towards', 'leave', etc.) are echoed by which AM morphemes?

5 An action realized at a transitional Ground ('go and do at a transitional place and leave again') can alternatively be interpreted as being concurrent motion with a punctual main action ('do once while going', see Koch, this volume), or as an action preceded and followed by a motion event (see Dryer, this volume ch.13). See also Guillaume \& Koch, this volume (§3.2). 


\section{Intra- and interspeaker variation}

Speakers may vary in terms of their AM inventories and in their use of their AM morphology (frequency and discourse use). In Mparntwe Arrernte, for instance, Wilkins (1991: 226, 229) observes ongoing semantic shifts in the systems of younger speakers (under 18) and mentions that not using AM morphemes is seen as "resorting to children's speech" or as being "uncooperative" if the path is known. Collecting data with a large variety of consultants may thus provide interesting clues in the domains of language acquisition or language decay.

In addition, the protocol in $\$ 3.3$ suggests different tasks to examine the use of AM morphology by the same speaker in different stories - using A Hunting Story vs. personal narrations.

\section{Cross-linguistic variation}

The data collected with the same stimulus in distinct languages should, in the longer term, facilitate cross-linguistic comparison between AM systems, again in terms of inventories, frequency and discourse use. It also helps the systematic study of AM as a functional domain rather than of AM morphology only. This onomasiological approach allows for the inclusion of any type of AM expression, instead of only those which consists of morphological markers.

\section{The stimulus kit}

\subsection{The AM storybook}

The AM storybook consists of 22 drawings. They feature an Ese Ejja person who goes hunting and experiences a series of subevents. Each scene was conceived as being potentially described with at least one type of AM morpheme of the kind that has been reported so far in at least one language. Each of the 22 scenes thus represents a main action that can be perceived in the framework of a journey. Picture 1 (\#14 in the picture book) illustrates the hunter rinsing his machete on his way back home, and one of the corresponding descriptions in Ese Ejja is found in (2a). Picture 2 (\#21 in the picture book) illustrates the mother monkey coming to steal her baby monkey back, and (2b) is a corresponding description.

$\begin{array}{lll}\text { (2) a. Ani-ñaki-o'oya-naje, } & \text { 'baa } & \text { shakwa-ka-ani. } \\ \text { sit-ARRIVE\&DO\&LEAVE-AGAIN-PST } & \text { machete } & \text { rinse-3A-PRS }\end{array}$ 'He stopped again (lit. he arrived, sat and then left) and rinses the machete.' $\{$ JulHS14\} 


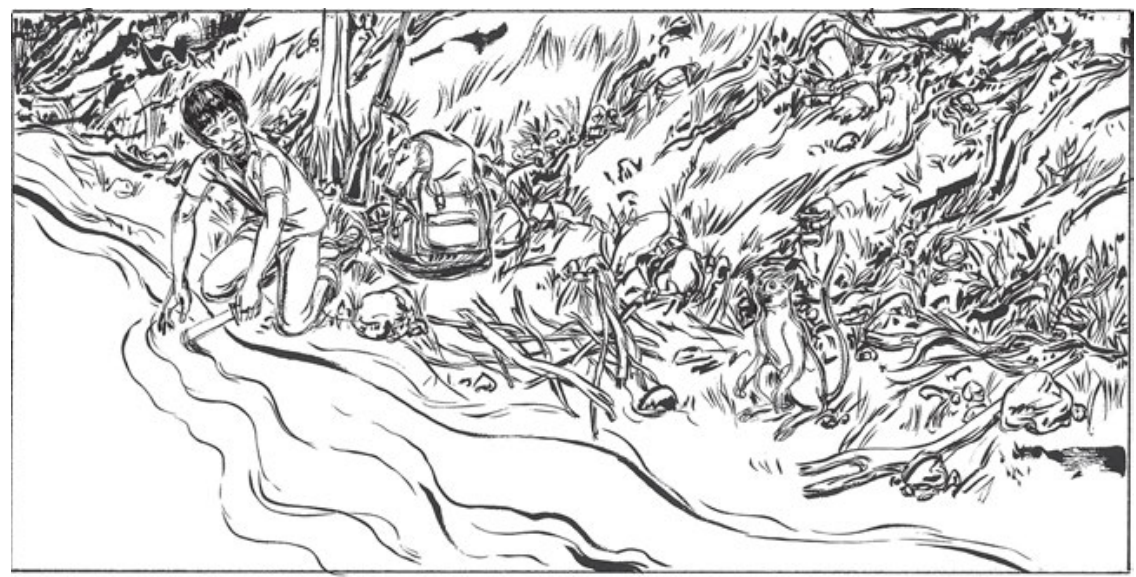

Picture 1: 'arrive \& sit \& leave' - ex. (2a)/\#14.

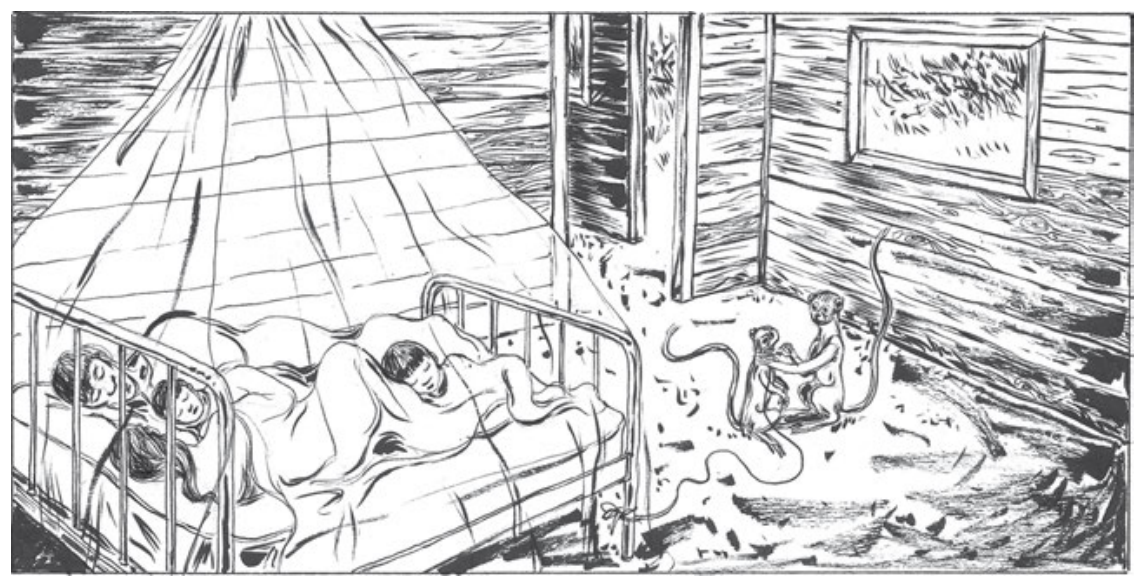

Picture 2: 'go to steal X' - ex. (2b)/\#21.
b. Sii-ki-ka-'io-naje
enaese $=a \quad 0=k a w i=j o=y a$. steal-GO.TO.DO-3A-TEL-PST mother=ERG $3=$ =sleep=TMP.DS=FOC 'She (the mother monkey) came (lit. went) to steal (her baby) back, the mother, when they were asleep.' \{JulHS21\}

Familiarity with the distinct main and backgrounded events is important, to guide the consultant during the familiarization phase through the many events depicted (Task 1, see $\S 3.3$ for a summary of the protocol), or to conduct more specific elicitation with a selection of pictures to test a given context. The first column of Table 1 summarizes the story picture by picture. The second column mentions the various 
Table 1: Detailed event account and AM morphemes expected.

\begin{tabular}{|c|c|c|}
\hline Pict. & Description of the picture & Targeted verb event and AM meanings \\
\hline \#1 & $\begin{array}{l}\text { A man is getting ready to go hunting, } \\
\text { checking his rifle. }\end{array}$ & check rifle BEFORE LEAVING (HOME) \\
\hline \#2 & $\begin{array}{l}\text { He leaves his home with his rifle; } \\
\text { he waves at his wife } \& \text { baby who } \\
\text { stand at the door, the boy is holding } \\
\text { back the dog who wants to follow } \\
\text { his master. }\end{array}$ & 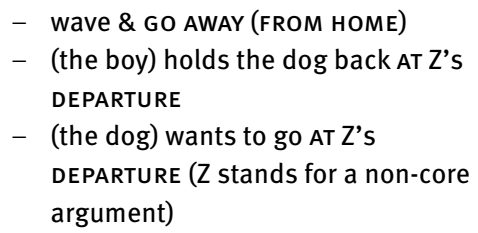 \\
\hline \#3 & $\begin{array}{l}\text { He walks past a field in which a couple is } \\
\text { working and they wave at each other. }\end{array}$ & wave / say hi PAST (A NEW PLACE) \\
\hline \#4 & He finds some fruits and collects them. & collect (punctual) WHEN GOING \\
\hline \#5 & $\begin{array}{l}\text { He loses fruits on his way because his bag } \\
\text { has a hole. }\end{array}$ & lose (atelic) WHEN GOING \\
\hline \#6 & $\begin{array}{l}\text { He is walking, is hot and tired (or: he chases } \\
\text { flies/mosquitoes). }\end{array}$ & 'be hot/tired' WHEN GOING \\
\hline \#7 & $\begin{array}{l}\text { He goes down to a river and drinks / refreshes } \\
\text { himself / fills his water sack. }\end{array}$ & $\begin{aligned}- & \text { GO DOWNWARD \& drink } \\
- & \text { drink WHILE STOPPING TRANSITORY } \\
& \text { (NEW PLACE) }\end{aligned}$ \\
\hline$\# 8$ & He walks again and feels much better. & $\begin{array}{l}\text { be happy WHEN RESTARTING A JOURNEY } \\
\text { AFTER A SHORT STOP (AT A TRANSITORY } \\
\text { PLACE) }\end{array}$ \\
\hline \#9 & He hears capybaras. & $\begin{array}{l}\text { - (the man) hear O (the capybaras) } \\
\text { COMING TOWARD A } \\
\text { - (the capybaras) hear O (the man) } \\
\text { COMING TOWARD A }\end{array}$ \\
\hline$\# 10$ & $\begin{array}{l}\text { He shoots one capybara out of three. } \\
\text { The other two run away in the opposite } \\
\text { direction. }\end{array}$ & 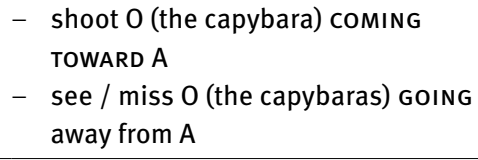 \\
\hline \#11 & $\begin{array}{l}\text { He puts the capybara into his bag (but it is too } \\
\text { big) and goes back home. }\end{array}$ & load AND RETURN HOME \\
\hline$\# 12$ & $\begin{array}{l}\text { Vultures try to get some pieces of meat / } \\
\text { attack him on his way. }\end{array}$ & $\begin{array}{l}\text { - be attacked WHILE RETURNING HOME } \\
\text { - attack WHILE O'S MOVING }\end{array}$ \\
\hline \#13 & $\begin{array}{l}\text { He disembowels the capybara and throws } \\
\text { the guts to the vultures so that they eat } \\
\text { them \& leave him in peace. }\end{array}$ & $\begin{array}{l}\text { disembowel/throw/ WHILE RETURNING / } \\
\text { WHILE STOPPING (AT A NEW PLACE) }\end{array}$ \\
\hline \#14 & $\begin{array}{l}\text { He goes back (down) to the river to refresh / } \\
\text { drink; he sees a baby monkey. }\end{array}$ & $\begin{array}{l}\text { drink WHILE RETURNING HOME / WHILE } \\
\text { STOPPING SHORTLY (AT A KNOWN PLACE) }\end{array}$ \\
\hline
\end{tabular}


Table 1 (continued)

\begin{tabular}{|c|c|c|}
\hline Pict. & Description of the picture & Targeted verb event and AM meanings \\
\hline \#15 & $\begin{array}{l}\text { He captures the baby monkey; the monkey's } \\
\text { mother witnesses the scene. }\end{array}$ & $\begin{array}{l}\text { capture O WHILE RETURNING HOME / } \\
\text { WHILE STOPPING SHORTLY (AT A KNOWN } \\
\text { PLACE) / BEFORE RETURNING HOME }\end{array}$ \\
\hline \#16 & $\begin{array}{l}\text { He passes by the field of the same couple, } \\
\text { who are interested in exchanging some meat } \\
\text { for bananas. }\end{array}$ & wave / say hi PAST BACK (KNOWN PLACE) \\
\hline \#17 & $\begin{array}{l}\text { His child runs towards him as he is arriving; } \\
\text { the monkey's mother (crying/hiding) has } \\
\text { followed him. }\end{array}$ & $\begin{array}{ll}\text { - } & \text { (Mother Monkey) hide/cry WHILE } \\
& \text { FoLLowING Z } \\
\text { - } & \text { run towards Z AT Z'S ARRIVAL } \\
\end{array}$ \\
\hline \#18 & $\begin{array}{l}\text { He ties the monkey with his rifle still on the } \\
\text { shoulder (= WHEN ARRIVING); the neighbor / } \\
\text { woman working in the field brings banana to } \\
\text { exchange them for meat. }\end{array}$ & $\begin{array}{ll}\text { - } & \text { tie WHEN ARRIVING } \\
\text { - } & \text { bring banana AT Z'S ARRIVAL } \\
\text { - } & \text { COME MOMENTARILY TO A PLACE TO } \\
& \text { bring/exchange banana } \\
\text { - } & \text { give X AT ARRIVING Somewhere AND } \\
& \text { RETURN } \\
\end{array}$ \\
\hline \#19 & $\begin{array}{l}\text { The neighbor / woman working in the field } \\
\text { leaves the house / goes back home with the } \\
\text { meat that was exchanged for bananas. }\end{array}$ & $\begin{array}{l}- \text { COME TO exchange } X \\
\text { - } \text { exchange } X \text { and LEAVE/RETURN }\end{array}$ \\
\hline \#20 & $\begin{array}{l}\text { The wife cooks the animal; the children play } \\
\text { around with their father \& the monkey; the } \\
\text { monkey's mother is looking through the } \\
\text { window. }\end{array}$ & $-\operatorname{cookX}$ BROUGHT \\
\hline \#21 & $\begin{array}{l}\text { The family sleeps at night, and the monkey's } \\
\text { mother sets him free. }\end{array}$ & - COME to free $X$ \\
\hline \#22 & $\begin{array}{l}\text { They both run back into the forest while } \\
\text { smiling / eating banana. }\end{array}$ & - run / steal banana + GO FOR GOOD \\
\hline
\end{tabular}

AM concepts targeted. (The main, non-motion event is written in lower case while the AM event is in small caps.) This table is actually the storyboard on which the illustrator Antoine Desnoyers based his work. He was asked to focus on the main action(s) of each scene, and to incorporate it/them in an environment familiar to the Ese Ejja, an environment to which he had had previous exposure.

\subsection{Ecology of the stimulus: an Amazonian setting}

Most linguists acknowledge that stimuli are useful in the process of data collection and documentation (see e.g. Lüpke 2009; Majid 2012) and even necessary for the careful investigation of specific semantic categories sometimes poorly represented 
in corpora (see e.g. Ponsonnet 2014; or San Roque et al. 2012). This subsection addresses the precautions taken for the Hunting Story stimulus to be as accessible as possible to people from non-WEIRD societies (for 'Western, Educated, Industrialized, Rich and Democratic', see Henrich, Heine \& Norenzayan 2010).

Miller (1973) had already pointed to two main ingredients for a pictorial stimulus to be easily recognizable: familiarity with the represented entity and familiarity with the pictorial cues. Therefore, the Hunting Story drawings represent actions occurring in an Amazonian setting which the Ese Ejja are familiar with. This resulted in that the Ese Ejja speakers and, more generally, most speakers from the Amazonian region who participated in the experiment, easily identified the pictorial representation, despite, or maybe because of the graphic density of the drawings. It was also found that even beyond Amazonia, consultants had no specific trouble understanding the pictures, as with Papitalai speakers from Papua New Guinea or Khaling speakers from Nepal, although the assumed identity of non-endemic entities was heavily discussed among the speakers - e.g. the capybara (a type of rodent) (A. Lahaussois, p.c. October 2018). The familiarity of the main storyline - people in a community living in wooden huts, cooking over the fire, collecting fruits and hunting in the forest, and fetching young animals to domesticate them - seems to have been transparent enough for speakers from very different environments.

People unfamiliar with Western modes of representation sometimes encounter difficulties understanding pictorial cues. Wilkins (1991: 217) mentions for instance the confusion of the Arrernte speakers with Western pictorial conventions depicting people lying rather than standing upright, because of the aerial view of events in Arrernte drawings. In drawing the pictures of the Hunting Story, Antoine Desnoyers avoided such techniques as 'shot-countershot' (where the viewpoint changes from one participant to another), which may not have been spontaneously understood by "non-Western” consultants.

To help gain familiarity with pictorial cues, Miller (1973) has emphasized the importance of the training phase: "the more experience an individual has with cues other than familiarity cues (e.g. depth cues, orientation cues), the greater the probability that he will be able to match a picture of an unfamiliar object with the actual object represented". (See also Cáceres (2017) on her experience with the Fish film in an Amazonian context.) This is the reason why the first task for this storybook is to leaf through the story with the consultant, discuss it, and make sure that he understands the succession of isolated pictures as a coherent story.

Note that elderly people seemed less at ease with the storybook, probably reflecting their limited exposure to Western modes of representation. As with any stimulus, the researcher should make sure that the consultant does not feel uncomfortable while completing any of the tasks. If such situations should arise 
(all the more likely in the context of linguistic insecurity), researchers are encouraged to limit stimulus use to other speakers more familiar with storybook narratives. The next section details the various steps of the protocol.

\subsection{The full protocol}

The full protocol consists of five tasks, detailed in a separate document available online (http://tulquest.huma-num.fr/fr/node/46). The list below is a summary.

Task 1. Becoming familiar with the story and describing each picture (in the target language). The goal of this task is threefold: (a) to make sure that the different drawings are easily interpreted and understood as a single story (cf. §2.2); (b) to highlight the presence of backgrounded elements that could be missed, like the hidden mother monkey who follows her captured baby; (c) to compare this first narrative to the second one (cf. re-telling the story in Task 2). If performed with several consultants, this first task is likely to give rise to interesting very natural discussions about the different perspectives of each speaker (see San Roque et al. 2012 for a similar primary task).

Task 2. Re-telling the story to a native speaker who does not know the story already so as to collect the most natural data in this artificial setting (see Himmelmann's (1998) "staged communicative events"). These first two steps should make it possible to test whether the consultant uses more AM morphemes once more familiar with the journey.

Task 3. Giving feedback to the researcher. Positive feedback included that the speakers were at ease and enjoyed themselves when performing the tasks the Ese Ejja really enjoyed finding elements from their everyday life in a storybook. Negative feedback included for instance issues with elderly people, due to sight problems or to their unfamiliarity with this kind of material. This third task is of importance for future users of the Hunting Story stimulus, and more generally for the design of future stimuli.

Task 4. Telling a complementary similar story. Besides obtaining more spontaneous data, the interest of collecting such complementary data is to compare the relative frequency of use of AM morphemes when the itinerary is maybe clearer in the consultant's mind, as in personal (or reported) experiences in a well-known environment, rather than a made-up story. Possible prompting questions could be the following: Did the story remind you of a personal experience, or of that of a friend? Could you tell me about your last / best hunting / fishing trip, or describe a typical day of hunting / fishing, or your last trip? 
Task 5. Looking for support from direct elicitation. As already mentioned above, yet another useful task is to test the felicity of known AM morphemes with the relevant pictures, even if they did not come up in Task 1 or 2. The visual support will facilitate working with a shared existing context and determining whether the use of a given AM morpheme is felicitous or not.

Task 6. Running The Pear Film experiment. At this point, the researcher could elicit another narrative using the well-known "Pear Film". (www.linguistics. ucsb.edu/faculty/chafe/pearfilm.htm). One of the main advantages of this video stimulus is the absence of a "real" home as a reference point, which can help investigate whether an AM morpheme is exclusively associated with homes or with more general reference points established in any journey.

Most Ese Ejja consultants performed the first three tasks in about half an hour. The three additional tasks lengthen the procedure considerably, which may be problematic in some fieldwork situations. These tasks are however fairly independent of one another and the researcher can plan to use them in subsequent sessions.

\subsection{Bonuses}

The stimulus did more than just collect comparable stories with AM morphemes. This subsection lists several extra goals accomplished with the stimulus, such as comparing dialectal variants (lexical and phonological differences), yielding several infrequent constructions (e.g. lest-clauses and mistaken belief constructions, cf. Spronk 2017), providing pedagogical material to teachers of the community, and establishing more confident relationships with speakers.

The storybook seems to enhance linguistic confidence in consultants. A Tacana consultant put great effort into a written version of the story, which ended up looking like a traditional story with reported speech markers (A. Guillaume, p.c. November 2013); such a written task can actually reassure insecure consultants and help them plan their story. K. Neely (p.c. October 2013) also noticed that the stimulus was not only a good springboard to get personal narratives for people unfamiliar and ill-at-ease with recording devices, but also a good introduction to more complex stimuli like Man and Tree (Levinson et al. 1992). She also reported that the Hunting Story stimulus had served as a basis for discussions between consultants, yielding interesting very spontaneous interactions involving questions, answers, explanations and disagreements about what certain images represented (as did A. Lahaussois, p.c. October 2018). 


\section{A pilot study: the Ese Ejja and the Hunting Story}

After a brief presentation of the Ese Ejja speakers and their language (§4.1), the present section discusses a pilot study run in 2013 with 14 Ese Ejja consultants who performed the first two tasks of the protocol. The data collected make use of half of the morphemes present in the Ese Ejja AM system (§4.2). Surprisingly, the data suggest that younger consultants do not necessarily produce fewer AM morphemes than older consultants, and that the consultants from the community with the best degree of vitality were not the ones who produced the most AM morphemes (§4.3).

\subsection{The Ese Ejja speakers and their language (and its AM system)}

Approximately 1,700 Ese Ejja live in southwestern Amazonia, in 9 villages in Bolivia and Peru. Ese Ejja (ISO 639-3: ese) is classified as a Pano-Takanan language, with approximately 1,500 Ese Ejja speakers and three variants: Madidi, Sonene and Baawaja. The Baawaja variant is the most distinct and is moribund; the Madidi and Sonene variants are very close and still used on a daily basis in most villages, but are not always transmitted to the younger generations (Vuillermet 2012b: 58, 69ff.). The data examined here include all three varieties and come from original fieldwork with consultants from five different communities located in Bolivia and Peru.

The language displays ergative alignment (ergative marker $=a$ and limited, third person Agent indexation -ka, see (2b)). Table 2 shows the morphological template for inflecting verbal predicates. A verb may appear with more than one

Table 2: Morphological template for verbal predicates.

\begin{tabular}{lllllllllllllll}
\hline-3 & -2 & -1 & 0 & +1 & +2 & +3 & +4 & +5 & +6 & +7 & +8 & +9 & +10 & +11 \\
\hline
\end{tabular}

\begin{tabular}{|c|c|c|c|c|c|c|c|c|c|c|c|c|c|c|}
\hline & & & & & & & & $\begin{array}{l}\frac{n}{0} \\
\frac{\pi}{0} \\
\frac{2}{2}\end{array}$ & & & & & & \\
\hline$\sum_{0}^{0}$ & $\begin{array}{l}\frac{3}{0} \\
\frac{0}{\pi} \\
\frac{0}{J}\end{array}$ & 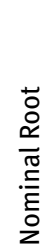 & 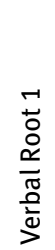 & 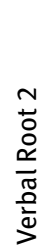 & 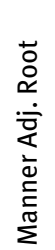 & $\begin{array}{l}\frac{n}{0} \\
\frac{\pi}{0} \\
\frac{0}{2} \\
\frac{2}{0} \\
\frac{1}{2}\end{array}$ & $\begin{array}{l}\vec{u} \\
\frac{\bar{v}}{\sqrt{0}} \\
\frac{10}{J}\end{array}$ & 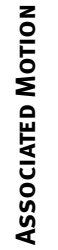 & 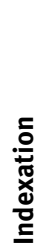 & 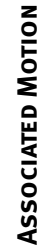 & 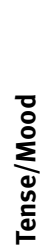 & $\begin{array}{l}\frac{n}{\pi} \\
\frac{0}{0} \\
\frac{2}{2} \\
\frac{2}{2}\end{array}$ & 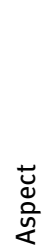 & 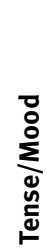 \\
\hline
\end{tabular}


root, as is for instance the case with noun incorporation or verb compounding. A full verb takes inflectional morphology (in bold), i.e. indexation (limited to third person) and tense or mood. AM morphology (in bold and small caps), together with adverbials and valency-changing morphology, belongs to the noninflectional morphology. Like most other non-inflectional categories, AM morphology appears in two different slots.

Table 3 classifies the 14 AM suffixes in Ese Ejja according to the three main parameters: 1) path/direction, 2) temporal relation to the non-motion main event, 3) moving argument.

Table 3: Ese Ejja AM system ${ }^{6} \&$ the morphemes used in the stimulus.

\begin{tabular}{|c|c|c|c|c|c|c|}
\hline & $\begin{array}{l}\text { IN THE } \\
\text { HUNTING } \\
\text { STORIES }\end{array}$ & & & $\begin{array}{l}\text { PATH / } \\
\text { DIRECTIONALITY* }\end{array}$ & $\begin{array}{l}\text { TEMPORAL } \\
\text { RELATION } \\
\text { TO THE EVENT }\end{array}$ & $\begin{array}{l}\text { MOVING } \\
\text { ARGUMENT }\end{array}$ \\
\hline 1 & $\checkmark$ & $-\tilde{n} a$ & 'do after arriving' & toward & prior motion & $\mathrm{S} / \mathrm{A}$ \\
\hline 2 & $\checkmark$ & -ñaki & ‘arrive\&do\&leave’ & toward\&away & 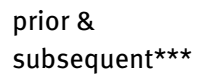 & \\
\hline 3 & $\checkmark$ & $-k i$ & 'go to do' & away from & prior + purpose & \\
\hline 4 & $\checkmark * *$ & $-w a$ & 'come to do' & toward & & \\
\hline 5 & $\checkmark$ & -poki & 'do while going' & away from & concurrent & \\
\hline 6 & $\checkmark$ & $-j e ’ b e$ & 'do while coming' & toward & motion & \\
\hline 7 & $\checkmark$ & $-n a n a$ & 'do\&leave' & away from & subsequent & \\
\hline 8 & $\checkmark$ & $-n a$ & 'do\&return’ & toward & motion & \\
\hline 9 & & -'aeki & 'do here\&there' & away from & $\begin{array}{l}\text { concurrent } \\
\text { motion }\end{array}$ & \\
\hline 10 & $\checkmark \star \star$ & -jjeki & 'come (0)’ & toward A & prior motion & 0 \\
\hline 11 & & $-n o ' b i$ & 'do while going in' & boundary & & $S / A$ \\
\hline 12 & & -kwaya & 'do while going out' & crossing & & \\
\hline 13 & & -sowa & $\begin{array}{l}\text { 'do while going } \\
\text { upstream' }\end{array}$ & $\begin{array}{l}\text { absolute frame } \\
\text { of reference }\end{array}$ & $\begin{array}{l}\text { concurrent } \\
\text { motion }\end{array}$ & $\mathrm{S} / 0$ \\
\hline 14 & & -'oke & $\begin{array}{l}\text { 'do while going } \\
\text { downstream' }\end{array}$ & & & \\
\hline
\end{tabular}

* See Vuillermet (2012a; 2012b: Chap. 15; 2013) for a thorough discussion of the semantics of the system.

** These two morphemes were only used after I suggested them (NB: not all suggestions were accepted).

$\star \star \star$ Alternatively analyzed a punctual aspectual realization away from the point of reference (do once while going away); see e.g. Guillaume (2009).

6 See Vuillermet (2012a, 2013) for a discussion of the semantics of the AM system. 


\subsection{AM morphemes collected in Ese Ejja}

Fourteen Ese Ejja consultants used the stimulus, eight males and six females, aged 7 to 73. One consultant spoke the Baawaja variant (from the Baawaja community), five the Sonene ( 4 from the community of Palmareal and 1 from Portachuelo Alto), and eight the Madidi (from Portachuelo Bajo).

Exactly half of the 14 AM morphemes present in the system were collected spontaneously, as shown in the second column of Table 3. Two additional morphemes (double-starred) were suggested by the researcher during Task 1, and repeated either during Task 1 or 2; see (4a) below for an illustration of one of these. The remaining five AM morphemes appear to be cross-linguistically less frequent in AM systems and were actually not targeted in any of the 22 pictures of the storybook: they encode distributed action \& motion (\#9), boundary crossing motion (\#11-12) and motion within an absolute frame of reference (\#13-14).

The following examples are Ese Ejja narratives of a A Hunting Story, and are presented with the corresponding pictures preceding the examples. The path/ directionality parameter is illustrated in (3a-b), and the temporal relation parameter in (4a-d). An additional parameter relevant to the Ese Ejja AM system, namely purpose of the main action is illustrated in (5).

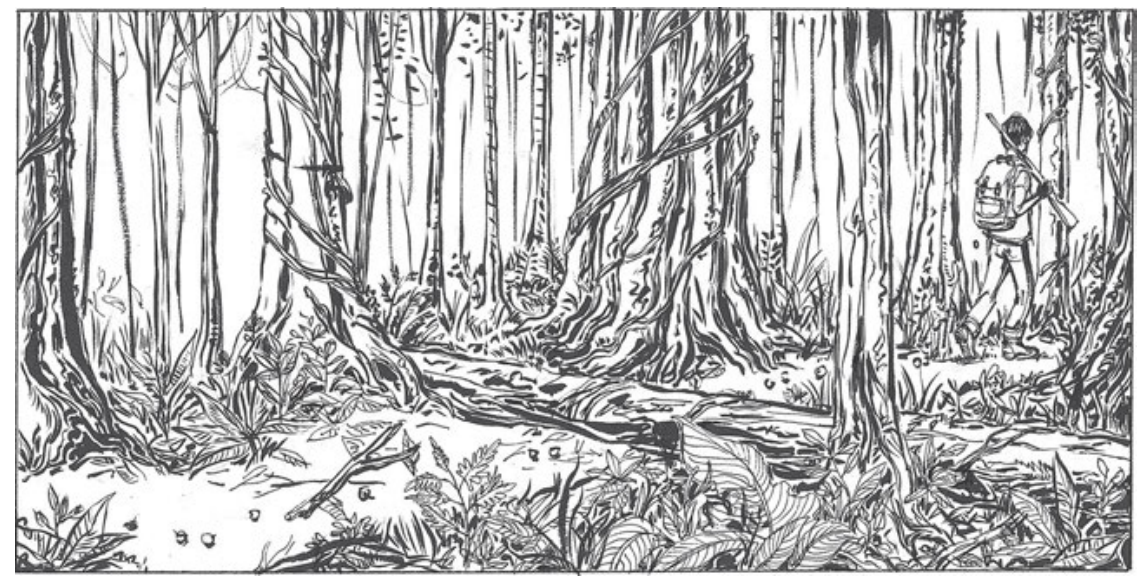

Picture 3: 'scatter $X$ while going' - ex. (3a)/\#5. 


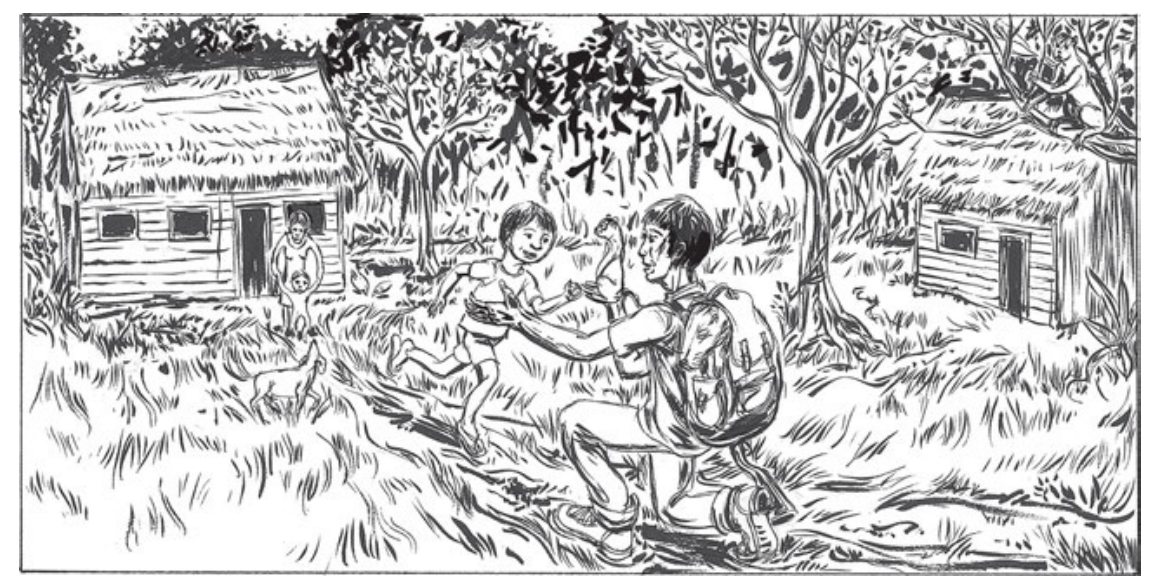

Picture 4: 'run while coming' - ex. (3b)/\#13.

(3) PATH / DIRECTIONALITY: do going (a), do coming (b)

a. Aekwá... e'a'bojji=pajja=me wejja-jji

what.is.it.again backpack=DISC=DISC hole-PROPR

jja-wojjajia-ki-poki-ani oya.

MID-scatter-MID-DO.GoING-PRS 3ABS

'And then what is it again... (his) backpack has a hole, he scatters it (while going).' $\{$ BawHSO5\}

b. E-'bakwa kwaji kwaji-je'be-ani akwe. ${ }^{7}$ NPF-child run RDP-DO.COMING-PRS CONFIRM

'The child comes running, doesn't he?' \{BawHS17\}

7 The AM morpheme -je'be 'Do.coming' occurs here with a motion verb, and it could thus be analyzed as being used as a directional, i.e. not expressing motion at all (see e.g. Dryer, this volume ch. 4 or Voisin, this volume). Such an analysis however implies that the motion component of -je'be is present only when used with a non-motion verb, and absent when used with a motion verb. I prefer analyzing the form kwajikwaji-je'be- as being redundant for motion, avoiding thus to resort to two semantic analyses depending on the verb type it collocates with. 


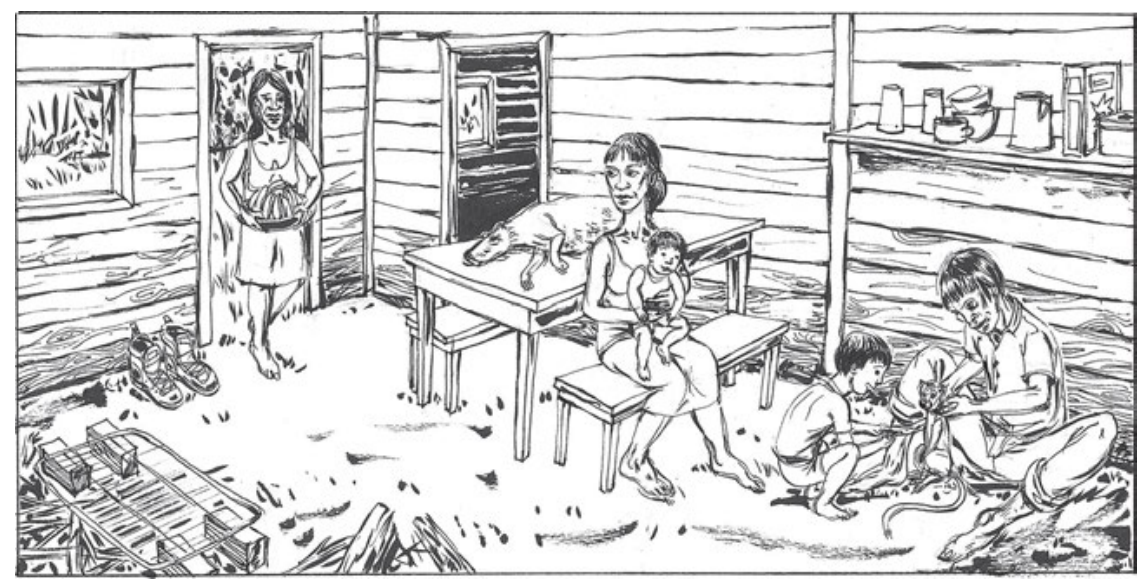

Picture 5: 'come to give' - ex. (4a)/\#18.

'lay $\mathrm{X}$ on the table at arrival' - ex. (4b).

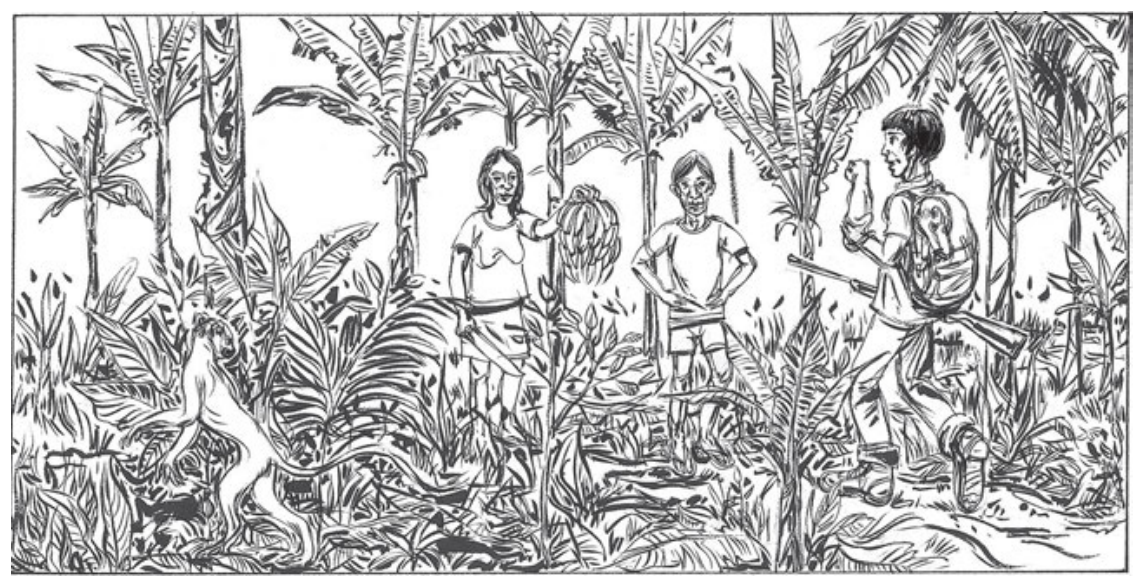

Picture 6: 'run after while coming' - ex. (4c)/\#16.

(4) TEMPORAL RELATION to the main event: prior (a-b), concurrent (c), prior \& subsequent (d)

a. Ejjawi kia-ka-wa-ani no? noe=sosejje. banana give-3A-CoME.To.Do-PRS no(Sp) meat=IN.EXCHANGE.FOR 'She comes to give banana, right? In exchange for meat.' $\{$ BawHS18 
b. Majoya kane owaya (...) mesa='biajje wana-ka-naje, then meat(Sp) 3ERG table=oN lay-3A-PST wana-ka-ña-'io-naje e-jaja-te'a-jji.

lay-3A-DO.ARRIVING-TEL-PST PURP-cut-tear.apart-PURP

'Then he laid the meat, he laid it onto the table when he arrived home, to cut it up.' $\{$ JulHS18\}

c. Okwekwaji-ka-je'be-ani, (e-naese) e-'bakwa run.after-3A-DO.COMING-PRS NPF-mother NPF-child ichaji-'oshe $=y a$ $e$-naese $=y a$, howling.monkey-white=ERG NPF-mother=ERG okwekwaji-ka-je'be-ani. ${ }^{8}$ run.after-3A-DO.COMING-PRS

'She runs after him, her child, the mother monkey, she runs after him.' $\{J u l H S 16\}$

d. 'Ba-ka-ñaki-naje kweyo. SEe-3A-ARRIVE\&DO\&LEAVE-PST fruit_sp 'He saw kweyo fruit on his way.' \{JulHSO4\}

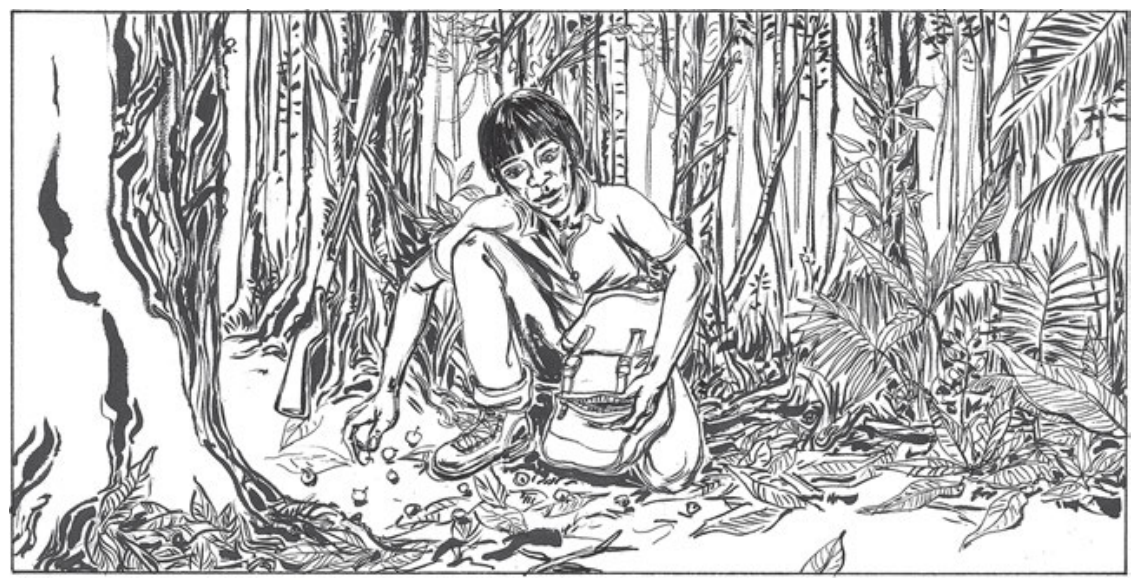

Picture 7: 'arrive \& see \& leave' - ex. (4d)/\#4. 


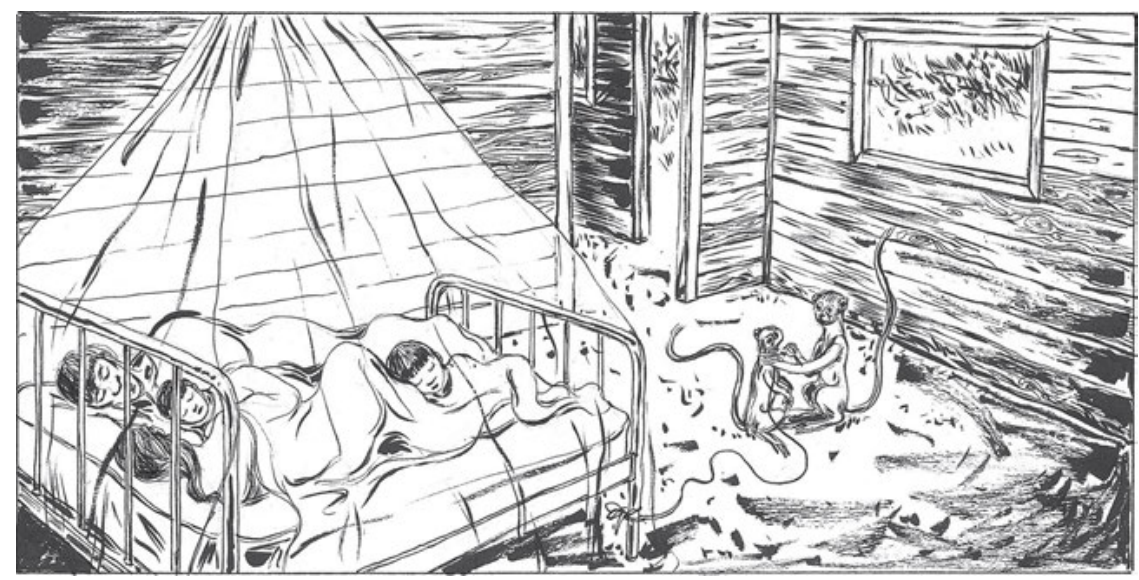

Picture 8: 'go to steal' - ex. (5)/\#21.

\section{(5) ADDITIONAL PARAMETERS: PRIOR MOTION AWAY + PURPOSE}

O-kawi-jo=ya meka=jje pojja'a sii-ki-ka-'io-naje.

3-sleep-TMP.DS=FOC night=PERL maybe steal-GO.TO.DO-3A-TEL-PST

'When they were sleeping, at night maybe, she goes to steal him (back)'. \{IzrHS16\}

\subsection{Preliminary results}

The storybook proved successful, yielding as many as 22 AM morphemes in a single narrative. As expected, there was also a lot of variation across consultants and across communities, and one consultant (from the Baawaja community, where the few Ese Ejja speakers no longer use their language daily) did not produce any AM morphemes.

In the context of a minority language mostly spoken by bilinguals, I was interested in examining whether the AM system, very typical of Ese Ejja, was losing ground. My two main research questions were thus primarily aimed at comparing the AM use across speakers of different ages and communities.

1. Do elderly speakers use more AM morphemes than younger ones?

2. Do speakers from communities where the language is best preserved use more AM morphemes than speakers from other communities?

The results were not straightforward. The two youngest consultants (7 and 10 years old) from Portachuelo Bajo actually produced up to 4 more AM morphemes 
than adults in the same community (whose members speak their native language daily at all ages). These results are even more surprising as the two young consultants are also very fluent in Spanish, unlike other Ese Ejja children of the same age. Children in this community still acquire (at least part of) the AM system, despite the heavy influence of Spanish in their everyday life, e.g. at school. Conversely, a 26-year-old woman in this same community produced only a single AM morpheme. Unfortunately, my sample did not include young consultants of the same age from other communities.

However, the young speakers mostly used lexicalized forms (other older speakers did too). A sheer count of the tokens misses important cues if it does not differentiate combination with a random action verb from more lexicalized forms like ani-ñaki- 'stop, lit. arrive and sit and leave or sit once on one's way', as using only the latter certainly points to a loss in productivity of the AM system.

Unsurprisingly, and as already mentioned above, the only consultant from the Baawaja community did not produce a single AM morpheme. However, consultants from the community of Palmareal, where language transmission is broken (but where people in their 30's still speak it daily), produced many more AM morphemes than consultants from Portachuelo Bajo, where the whole population speaks the language daily. In addition, the Palmareal consultants used the AM morphemes more productively, with a wider range of verbs.

One possible factor that could have triggered a higher production is the degree of comfort with the task. The Palmareal consultants seemed to have enjoyed themselves the most in telling the story, producing very flowing stories (e.g. with dialogues between the characters as in ex.(1)), while the production of the Portachuelo Bajo consultants was more halting. However, enjoyment was not the only factor at play. At least one of the Portachuelo Bajo consultants told a very fluid and lively story (with lots of discourse particles and interaction with his audience) and produced only two AM morphemes. This consultant is a politician and is therefore more exposed to Spanish than most other Ese Ejja, something which could have influenced his production. These results suggest, on the one hand, the need for limiting the number of variants (age vs. gender vs. community vs. education level, etc.), i.e. targeting a less heterogenous sample. On the other hand, having access to a detailed picture of the individual language use allows researchers to take into account finer-grained sociolinguistic parameters that are key in interpreting the results from such an experiment. 


\section{Hunting stories in other languages: preliminary results}

This section shows the kind of utterances elicited with the Hunting Story in several other languages, mostly spoken in the Amazonian region, but also much further beyond, in Asia and Oceania. Table 4 shows that eight researchers used the stimulus, yielding interesting AM constructions in most cases. ${ }^{9}$

Table 4: List of the languages for which Hunting Stories have been recorded, and the researchers.

\begin{tabular}{llll}
\hline Choapan Zapotec & Oto-Manguean & North America & Erin Donnelly \\
\hline Purepecha & Tarascan & South America & Alejandra Capistran \\
\hline Máíh̃̈ki & Tukanoan & Peru & Lev Michael \\
\hline Yaminahua & Pano-Takanan & Peru & Kelsey Neely \\
\hline Tacana & Pano-Takanan & Bolivia & Antoine Guillaume \\
\hline Dâw & Nadahup & Brazil & Karolin Obert \\
\hline Thulung & Sino-Tibetan, Kiranti & India; Nepal & Aimée Lahaussois \\
\hline Papitalai (Koro dialect) & Austronesian, Oceanic & Papua New Guinea & Jessica Cleary-Kemp \\
\hline
\end{tabular}

Some languages tested have morphological AM systems. The first two examples are from Tacana (A. Guillaume, p.c. November 2018), a language with a very complex system of 13 morphemes (Guillaume 2017: 224), and display two AM morphemes that respectively encode prior and concurrent motion.

(6) a. Y-asease-ti =da ema e-wane.

FUT-hunt-Go.TO.Do $=$ PTC $1 \mathrm{SG}$ NPF-wife

"I'm going to go to hunt (in the jungle), my wife" (the man said to his wife)' $\{$ ye008HS01\}

b. Senda=je e-uru-u tumi =mu.

path=PERL IPFV-fall-IPFV.GoING motacú_palm =CONTR

'The motacú nuts were falling along the path (from the hunter's bag.)' \{ye008HS5

9 Two researchers reported that their consultants did not produce the expected AM morphology, but I did not see their data and do not know if and how the consultants possibly co-expressed the motion and non-motion events instead. Note that the following examples are courtesy of various researchers. They are only illustrating the kind of AM expression collected with the stimulus, and in depth analyses fall out of the scope of this paper. 
Yaminahua (K. Neely, p.c. November 2018) also has a very complex AM system of 11 morphemes. In addition to this, the language has a multi-verb construction associating a non-finite verb with the auxiliary $k a$ - 'go'. The three examples below illustrate (a) an AM morpheme used alone, (b) the multi-verb construction with $k a$ - 'go', and (c) an AM morpheme on a non-finite verb, within the multi-verb construction with $k a$ - 'go'. (Note the intransitive/transitive allomorphy of -kai -waid 'do.going' in (7a) and (7c).)

(7) a. wibi=Ø pake-kai-i

fruit=ABS fall-DO.GOING.INTR.SG-IPFV

'The fruit is going falling.' $\{0159 \mathrm{HS} 05\}$ (The fruit is falling from the backpack of the hunter.)

b. afimefi= $\varnothing \quad$ ichu-i $\boldsymbol{k} \boldsymbol{a}-\boldsymbol{i}$

capybara=ABS escape-NF go.sG-IPFV

'The capybara(s) are going to escape / going running.' \{0159HS10

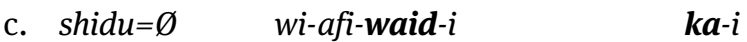

monkey=ABS take-MAL-GO.DOING.TR-NF go.SG-IPFV

'(He’s) taking the monkey (to its mother's detriment) as he goes.' \{0165HS15-16\}

By contrast, the Hunting Story in Thulung (A. Lahaussois, p.c. October 2018), did not contain the single AM morpheme the language has. ${ }^{10}$ Instead, plain motion verbs where used and coordinated with a general conjunction - $m a$ that can also combine non-motion events to a concurrent motion event as (8a) or a prior motion event to a non-motion event (8b). (Note how the capybara, absent from Nepal, was interpreted as a deer.)

me sekhli bu:-ru-ma $\quad$ der
DEM hunt do-3SG>3SG.PST-CONJ deer
kur-rt-mar-ta-lo
carry-3SG>3SG.PST-CoNJ come-3SG.PST-TEMP
'when he hunted and carried the deer and came'

10 This AM morpheme encodes distributed motion (called "ambulative" by A. Lahaussois) and might correspond to the morpheme -'aeki 'do here \& there' in Ese Ejja. Distributed motion is not specifically represented in the pictures of A Hunting Story and is also absent from the Ese Ejja narratives collected with this storybook. 


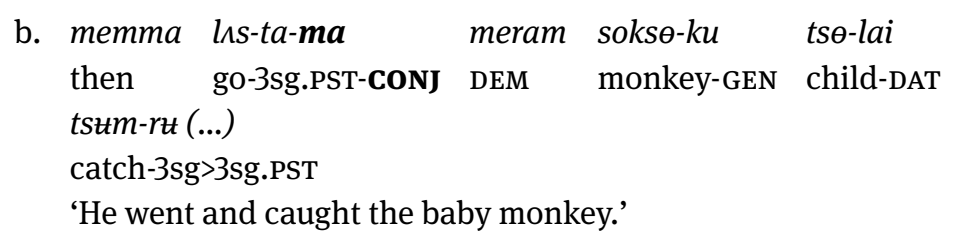

Other languages tested do not have morphological AM systems. For instance, the Dâw consultants used a serial verb construction as illustrated in (9) (K. Obert, p.c. October 2018). The construction seems to express concurrent events only.

(9) a. dâw xut soob ween rãm $k a$ '

person $M$ hand wave go PROG

'The man was waving (while) going' $\{\mathrm{HS} 2\}$

b. dâw xut yêd yâa tir nũr-ũuy person $M$ hide return 3sG.Poss head-DoM 'The man goes back (home) (while) hiding his head (from the vultures)' $\{$ HS12 $\}$

Unlike Dâw, Papitalai (J. Cleary-Kemp, p.c. November 2018) used a sequential AM serial verb construction, with le or la 'go to' as V1 and a main action verb as V2. It indifferently expresses 'go and V2' or 'go to V2', as in (10a). Cleary-Kemp reports that this construction is extremely common in Koro narratives and appeared a lot in A Hunting Story. In addition, two bi-clausal constructions were also frequent: one with two main clauses, conjoined with $m w a$ 'and' or simply juxtaposed with no coordinator; and a (semantically) subordinate clause ${ }^{11}$ with taim 'when/while' and a "main" clause. These were usually connected with coordinator mwa. In (10b), the first clause is a (semantically) subordinate clause, indicated by taim 'when'. (Note in this last example how the vulture was interpreted as a sea eagle.)

a. ayou $k$-u le kah nderi tih pu ne, tih
1SG.SBJ IRR-1SG go.to look.for small one pig or one
lawat ne, tih cha
cuscus or one what
'I am going to go to look for a small pig, or a cuscus, or whatever.'
\{HS1-2, Mary Clara Hinduwan v2013-07-30-AV-01 00:00:30

11 There is no morphological indication on either of the verbs that this is a subordinate clause construction. 
b. Taim $i$ ri la, mwa menuwai $i$ when/while 3 sg stay walk coord sea.eagle 3sG hung-eya Ø smell-TR3SG.INAN.OBJ

"He was walking and a sea eagle smelled it (the pig)" (p.12 of the story, Mary Clara Hinduwan v2013-07-30-AV-01 00:03:50)

Finally, Máíhĩki (Lev Michael, p.c. November 2018) used clause chaining. Interestingly, it is the verb of motion (mostly 'go') that is finite and appears in the main clause, while the activity verbs are not finite and appear in multiple non-finite (nominalized) chained subordinate clauses, with either simultaneous or sequential markers on them. The two examples in (11) show two types of "simple" subordinate clauses (simultaneous vs. sequential), and (12) shows two types of multiple chained subordinate clauses.
a. [Hásu deba-re]
máká sái-hí. shotgun put.in.order-SUB.SEQ.SS forest go-3M.SG.PRS 'Having put his shotgun in order, he goes to the forest.'

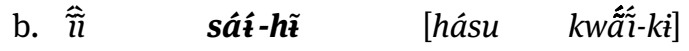
3sg.PRO go-3M.SG.PRS shotgun carry.on.shoulder-SUB.SIM.sS
'He goes carrying his shotgun on his shoulder.'

(12)
a. [néá-re] sấíthĩ, yuara-re
grab-SUB.SEQ.SS go-3MASC.SG.PRES paca-ACC [bee-ki] carry.on.back-SUB.SIM.sS

'Having grabbed (it), he goes, carrying the paca on his back.'

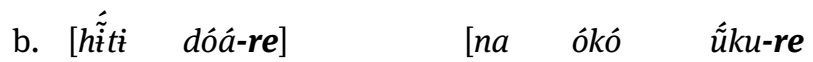 hand wash-SUB.SEQ.SS again water drink-SUB.SEQ.SS

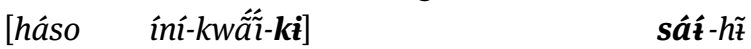 shotgun get-carry.on.shoulder-SUB.SIM.ss go-3M.SG.PRS 'Having washed his hands, having drunken water again, getting and carrying his shotgun on his shoulder, he goes.'

This section has shown that $A$ Hunting Story proves to be an efficient tool to not only collect AM morphology but also a variety of non-morphological constructions co-expressing motion and non-motion events. The many patterns attested show constructions ranging from mono-clausal to multi-clausal ones, including 
grammatical (AM), semi-grammatical (auxiliaries), semi-lexical $\left(\mathrm{SVCs}^{12}\right)$ and lexical means (full lexeme \& subordinated/coordinated clauses).

\section{Conclusion}

The storybook A Hunting Story is the first visual stimulus designed to elicit motion events in the background of main, (prototypically) non-motion events. It can serve various goals, from descriptive (collection of AM morphology and constructions) or sociolinguistic (comparison across speakers and communities), to typological ones (comparison across languages). Designed for linguistic fieldwork in nonurban communities, special attention was given to the ecology of the story itself (an everyday hunting activity) and its setting (an ordinary-looking wooden house with a thatched roof, dense vegetation, etc.). It is noticeable that consultants from very distinct origins have welcomed and enjoyed the storybook, with some even using it as pedagogical material. Nevertheless, as with any methodological tool, success always depends on the consultant's preparation to the task.

The first results presented in this paper show that the collection of morphological AM was successful in most cases and yielded AM morphemes, as long as the pictures represented the targeted AM concepts. In the future, it may be worth adding some pictures that represent less frequent AM morphemes, such as absolute-frame-of-reference motion co-events ('do while going up/downriver') or boundary-crossing ones ('do while going in/out'). If used for descriptive and sociolinguistic goals, the researcher needs to be well aware of the sociolinguistic profile and language use of each consultant.

Although initially designed for morphological AM, the storybook opens the possibility of comparing the variety of strategies used to co-express motion and non-motion events in an onomasiological approach. Is the Máíhĩki strategy of clause chaining governed by the motion verb typical across languages? Do languages with AM morphology use bi-clausal strategies in addition to AM morphology? A Hunting Story will hopefully become an essential part of the toolkit for fieldworkers and will help to build a comparative corpus that will enrich our understanding of the co-expression of motion events.

12 In the sense that SVCs have a conventionalized order, and are thus not "pure lexical constructions". 


\section{Abbreviations}

The abbreviations used follow the Leipzig Glossing Rules, except for the following ones:

$\begin{array}{llllll}\text { APF } & \text { adjective prefix } & \text { FUT } & \text { future } & \text { RDP } & \text { reduplication } \\ \text { CONJ } & \text { conjunction } & \text { MAL } & \text { malefactive } & \text { SEQ } & \text { sequential } \\ \text { CONTR } & \text { contrastive } & \text { MID } & \text { middle } & \text { SIM } & \text { simultaneous, } \\ \text { DISC } & \text { discourse particle } & \text { NF } & \text { non-finite } & \text {-SP } & \text { species } \\ \text { DOM } & \text { differential object } & \text { NPF } & \text { noun prefix } & \text { SS } & \text { same subject } \\ & \text { marker } & \text { PERL } & \text { perlative } & \text { SUB } & \text { subordinate } \\ \text { DS } & \text { different subject } & \text { PRO } & \text { pronoun } & \text { TEL } & \text { telic } \\ \text { INAN } & \text { inanimate } & \text { PROPR } & \text { proprietive } & \text { TMP } & \text { temporal } \\ \text { INCL } & \text { inclusive } & \text { PTC } & \text { particle } & & \text { (subordinator). }\end{array}$

Acknowledgements: This research has been supported by a one-year grant from the Fyssen Fundation in 2012-2013 at UCB and the paper was finalized during a postdoctoral fellowship from LABEX ASLAN (ANR-10-LABX-0081) of the Université de Lyon within the program "Investissements d'Avenir" (ANR-11-IDEX-0007). I want to thank Antoine Desnoyers for the beautiful work he achieved and his patient collaboration. My thanks go to the Ese Ejja people, who taught me their language with much patience and friendship over the years. I am grateful to Lev Michael who has been a great sponsor during my postdoctoral stay at the University of California at Berkeley. I am very indebted in Jessica Cleary-Kemp, Antoine Guillaume, Aimée Lahaussois, Lev Michael, Kelsey Neely, and Karolin Obert for having enthusiastically used the stimulus and shared their data for the present paper. I am very grateful to Antoine Guillaume and Harold Koch for having accepted this original contribution to their volume, and for their constructive comments and those of Aimée Lahaussois, which helped me to greatly improve the paper. All remaining mistakes are, of course, my own. 


\section{References}

Cáceres, Natalia. 2017. Adapting experimental visual stimuli protocols for wider use. Presented at the Workshop on questionnaires for linguistic description and typology, University of Paris Diderot, Paris, France, November 9.

Dryer, Matthew S. This volume, chapter 4. Associated motion and directionals: Where they overlap.

Dryer, Matthew S. This volume, chapter 13. Associated Motion in North America (including Mexico and Central America).

Guillaume, Antoine. 2006. La catégorie du mouvement associé en cavineña: Apport à une typologie de l'encodage du mouvement et de la trajectoire. Bulletin de la Société Linguistique de Paris 415-436.

Guillaume, Antoine. 2009. Les suffixes verbaux de "mouvement associé" en cavineña. Les Cahiers de Faits de Langues 1. 181-204.

Guillaume, Antoine. 2016. Associated motion in South America: Typological and areal perspectives. Linguistic Typology 20(1). 81-177.

Guillaume, Antoine. 2017. Sistemas complejos de movimiento asociado en las lenguas de las familias Tacana y Pano: perspectivas descriptiva, comparativa y tipológica. In Antoine Guillaume \& Pilar Valenzuela (eds.), Amerindia (Numéro thématique: Estudios sincrónicos y diacrónicos sobre lenguas Pano y Takana: fonología, morfología y sintaxis) 39(1). 211-261.

Guillaume, Antoine \& Harold Koch. This volume, chapter 1. Introduction: Associated motion as a grammatical category in linguistic typology.

Hellwig, Birgit. 2006. Field semantics and grammar-writing: Stimuli-based techniques and the study of locative verbs. In Felix K Ameka, Alan Charles Dench \& Nicholas Evans (eds.), Catching language: The standing challenge of grammar writing, 321-358. Berlin \& New York: M. de Gruyter.

Henrich, Joseph, Steven J. Heine \& Ara Norenzayan. 2010. The weirdest people in the world? Behavioral and Brain Sciences 33(2-3). 61-83. doi:10.1017/S0140525X0999152X.

Himmelmann, Nikolaus P. 1998. Documentary and Descriptive Linguistics. Linguistics 36. 161-195.

Koch, Harold. 1984. The category of "associated motion" in Kaytej. Language in Central Australia 1. 23-34.

Koch, Harold. This volume, chapter 7. Associated Motion in the Pama-Nyungan languages of Australia.

Kopecka, Anetta \& Bhuvana Narasimhan (eds.). 2012. Events of putting and taking: $A$ crosslinguistic perspective (Typological Studies in Language 100). Amsterdam \& Philadelphia: John Benjamins.

Lahaussois, Aimée. 2019. The TULQuest linguistic questionnaire archive. Language Documentation \& Conservation 16 [Special issue Methodological tools for linguistic description and typology edited by Aimée Lahaussois \& Marine Vuillermet]. 97-123.

Levinson, Stephen C., Penelope Brown, Eve Danzinger, Lourdes De León, John B. Haviland, Eric Pederson \& Gunter Senft. 1992. Man and Tree \& Space games. doi:10.17617/2.2458804. http://pubman.mpdl.mpg.de/pubman/item/escidoc:2458804 (8 November, 2018).

Levinson, Stephen C., Sergio Meira \& Language and Cognition group, Max Planck Institut für Psycholinguistics Netherlands. 2003. "Natural concepts" in the spatial topological 
domain-Adpositional meanings in crosslinguistic perspective: An exercise in semantic typology. Language 79(3). 485-516. doi:10.1353/lan.2003.0174.

Lüpke, Friederike. 2009. Data collection methods for field-based language documentation. Language Documentation and Description 6. 53-100.

Majid, Asifa. 2012. A guide to stimulus-based elicitation for semantic categories. In Nicholas Thieberger (ed.), The Oxford handbook of linguistic fieldwork, 54-71. New York: Oxford University Press.

Miller, Robert J. 1973. Cross-cultural research in the perception of pictorial materials. Psychological Bulletin 80(2). 135-150.

Payne, Thomas. 1984. Locational relations in Yagua narrative. Work Papers of the Summer Institute of Linguistics 28. 157-192.

Ponsonnet, Maïa. 2014. Documenting the language of emotions in Dalabon (Northern Australia): Caveats, solutions and benefits. In Aicha Belkadi, Kakia Chatsiou \& Kirsty Rowan (eds.), Proceedings of the Conference on Language Documentation and Linguistic Theory 4, 1-13. School of Oriental and African Studies, University of London.

Rose, Françoise. 2015. Associated motion in Mojeño Trinitario: Some typological considerations. Folia Linguistica 49(1). 117-158. doi:10.1515/flin-2015-0004.

San Roque, Lila, Lauren Gawne, Darja Hoenigman, Julia Colleen Miller, Alan Rumsey, Stef Spronk, Alice Carroll \& Nicholas Evans. 2012. Getting the story straight: Language fieldwork using a narrative problem-solving task. Language Documentation and Conservation 6. 135-174.

Spronk, Stef. 2017. Reckoning wrong: Mistaken belief in Australian Aboriginal languages as a window onto the syntax of perspective. Presented at the 12th Conference of the Association for Linguistic Typology (ALT), Canberra, Australia, December 12.

Voisin, Sylvie. This volume, chapter 16. Associated Motion and Deictic Directional in Atlantic languages.

Vuillermet, Marine. 2012a. Une typologie en cheminement : Contribution de l'ese ejja à l'étude du mouvement associé. In Caroline Imbert \& Nathalie Vallée (eds.), LIDIL, 79-100.

Vuillermet, Marine. 2012b. A grammar of Ese Ejja, a Takanan language of the Bolivian Amazon. Université Lumière Lyon 2 Doctoral dissertation.

Vuillermet, Marine. 2013. Dónde, cuándo, y con quién ocurren acciones: El movimiento asociado en ese ejja. In Ana María Ospina (ed.), Expresión de nociones espaciales en lenguas amazónicas, 33-53. Bogota: Universidad Nacional de Colombia e Instituto Caro y Cuervo.

Vuillermet, Marine \& Antoine Desnoyers. 2013. A hunting story - Yendo a cazar: A visual stimulus for eliciting constructions that associate motion with other events. Linguistic Department, UC Berkeley, ms. http://tulquest.huma-num.fr/fr/node/46.

Wilkins, David P. 1991. The Semantics, pragmatics and diachronic development of "Associated Motion" in Mparntwe Arrernte. Buffalo Papers in Linguistics 207-257. 
